Article

\title{
Effects of Forage Rice Cultivation on Carbon and Greenhouse Gas Balances in a Rice Paddy Field
}

\author{
Fumiaki Takakai * (D), Masahiro Kobayashi, Takashi Sato, Kentaro Yasuda and Yoshihiro Kaneta \\ Laboratory of Soil Science, Faculty of Bioresource Sciences, Akita Prefectural University, 241-438 Aza \\ Kaidobata-Nishi, Shimoshinjo Nakano, Akita 010-0195, Japan; koido_1223@yahoo.co.jp (M.K.); \\ t_sato@akita-pu.ac.jp (T.S.); kentaroy@akita-pu.ac.jp (K.Y.); ykaneta@akita-pu.ac.jp (Y.K.) \\ * Correspondence: takakai@akita-pu.ac.jp or ftakakai@gmail.com; Tel.: +81-18-872-1612; Fax: +81-18-872-1677
}

Received: 5 December 2018; Accepted: 16 December 2018; Published: 19 December 2018

\begin{abstract}
The effects of conversion from staple rice to forage rice on carbon and greenhouse gas (GHG) balances in a paddy field were evaluated. A staple rice plot without the application of livestock manure compost (LMC, $\mathrm{S}-\mathrm{M}$ plot) and forage rice plots with and without the application of LMC, derived mainly from cattle ( $2 \mathrm{~kg}-\mathrm{FW} \mathrm{m}{ }^{-2}, \mathrm{~F}+\mathrm{M}$ and $\mathrm{F}-\mathrm{M}$ plots, respectively), were established. $\mathrm{CH}_{4}$ and $\mathrm{N}_{2} \mathrm{O}$ fluxes and $\mathrm{CO}_{2}$ flux from a bare soil plot for organic matter decomposition (OMD) were measured. The carbon budget was calculated by subtracting the $\mathrm{OMD}, \mathrm{CH}_{4}$ emission, and harvested grain and straw (forage rice only) from the net primary production and LMC. The net GHG balance was calculated by integrating them as $\mathrm{CO}_{2}$ equivalents. There were no significant differences in GHG flux among the plots. Compared to the carbon loss in the S-M plot, the loss increased by harvesting straw and was mitigated by LMC application. The net GHG emission in the $\mathrm{F}+\mathrm{M}$ plot was significantly lower than that in other plots $\left(1.78\right.$ and $2.63-2.77 \mathrm{~kg} \mathrm{CO}_{2}$-eq m${ }^{-2}$ year $^{-1}$, respectively). There is a possibility that GHG emissions could be suppressed by forage rice cultivation with the application of LMC.
\end{abstract}

Keywords: carbon dioxide; livestock manure compost; methane; nitrous oxide; organic matter decomposition; whole-crop silage

\section{Introduction}

Currently, the Japanese self-sufficiency rate of feed is $27 \%$ (total digestible nutrients base, average from 2013-2016) [1], and livestock production in Japan is highly dependent on imported feed which has an unstable price. For stable livestock production, it is necessary to increase domestic feed production. On the other hand, in Japanese paddy fields, conversion from the cultivation of staple rice (Oryza sativa L.) to other crops (adjustment of rice production) has been conducted over 40 years to suppress the over-production of rice. The production of forage crops, such as grass and maize, in uplands converted from paddy fields has been recommended to improve the feed self-sufficiency rate. However, forage crop production in converted paddy fields with poor drainage is generally low and it tends to be unstable, and the improvement of drainage through the construction of open ditches and underdrains is necessary. Therefore, as an alternative to imported feed, forage rice, which can utilize paddy field as it is, could be cultivated. Forage rice consists of "whole-crop silage (WCS)", which utilizes panicles, leaves, and stems, and "rice for feed", which utilizes rice grains or brown rice only. The area of forage rice cultivation in Japan increased from 722 ha in 2000 (WCS: 502 ha, rice for feed: 220 ha) to 134,443 ha in 2018 (WCS: 42,893 ha, rice for feed: 91,540 ha) [1]. Varieties of forage rice with high dry matter production and high lodging resistance have been bred [2,3].

Inappropriate management of livestock manure causes bad odors and nutrient leaching followed by the pollution of groundwater and rivers. In Japan, the "Law on Promoting Proper Management and 
Use of Livestock Excreta" aimed at appropriately managing livestock excreta and promoting effective utilization as a resource was enforced in 1999. It is expected that livestock manure compost will be used as a soil improvement material and fertilizer. Also, it has become possible to establish a forage rice production system for resource cycling, a so-called "connection between cultivating and livestock based on paddy field", by supplying forage rice to livestock and applying manure compost derived from the livestock to the paddy field [4].

In current staple rice cultivation in Japan, harvest is conducted mainly by combine harvester and rice straw is scattered over the surface of paddy field simultaneously. Generally, soil carbon storage in paddy fields with rice straw application are maintained by supply of carbon derived from rice straw (e.g., [5,6]). Rice cultivation is a major source of methane $\left(\mathrm{CH}_{4}\right)$, a major greenhouse gas $(\mathrm{GHG})$, accounting for about $45 \%$ of total anthropogenic $\mathrm{CH}_{4}$ emission from Japan [7]. It has been widely reported that application of rice straw to paddy fields significantly increases the $\mathrm{CH}_{4}$ emission [8-10].

In forage rice cultivation for WCS, all of the aboveground plant biomass is harvested and utilized, so this rice straw is not returned to the paddy fields. Therefore, the carbon loss from the field with forage rice cultivation may increase compared to that of staple rice cultivation. On the other hand, the application of livestock manure compost to the forage rice cultivation field greatly increases the carbon supply and improves the carbon balance. Meanwhile, the supply of organic matter as livestock manure compost to the field could promote the production and emission of GHGs, such as carbon dioxide $\left(\mathrm{CO}_{2}\right), \mathrm{CH}_{4}$, and nitrous oxide $\left(\mathrm{N}_{2} \mathrm{O}\right)$. As mentioned above, the introduction of forage rice cultivation may greatly change the carbon and GHG balances of paddy fields.

Therefore, in this study, we comprehensively evaluated the effects of forage rice cultivation on the carbon and GHG balance of paddy fields. As the conversion from edible rice to feed rice is expected to increase, the GHG balance at the first year of conversion was especially evaluated.

\section{Materials and Methods}

\subsection{Experimental Field, Setup, and Cultivation}

The experiment was conducted at a continuous rice paddy field in the Field Education and Research Center of Akita Prefectural University $\left(40^{\circ} 00^{\prime} \mathrm{N}, 139^{\circ} 57^{\prime} \mathrm{E}\right)$ in the Akita Prefecture, Northern Japan for one year (May 2011-May 2012).

Three experimental plots were established in this study: a staple rice (variety: Akitakomachi) cultivation plot without application of livestock manure compost (LMC, S - M plot) and forage rice (variety: Bekoaoba) cultivation plots both with and without the application of LMC, derived mainly from cattle $\left(2 \mathrm{~kg}-\mathrm{FW} \mathrm{m}{ }^{-2}, \mathrm{~F}+\mathrm{M}\right.$ and $\mathrm{F}-\mathrm{M}$ plots, respectively). Two sub-plots $(3 \times 3 \mathrm{~m})$ were established for each experimental plot. Greenhouse gas flux measurement and rice plant investigation at the harvest stage were carried out in duplicate within each sub-plot, and the values were averaged (described below in Section 2.2). Bekoaoba is a forage rice variety for WCS use that is suitable for this region, and it has high lodging resistance under high nitrogen fertilizer application conditions [11,12].

The soil type in the studied field was classified as a gley lowland soil (Eutric Fluvisols [13]). The chemical properties of the studied soil, which were obtained from a depth of $0-10 \mathrm{~cm}$ prior to this study, were as follows: $\mathrm{pH}\left(\mathrm{H}_{2} \mathrm{O}\right), 7.6$; total nitrogen, $3.6 \mathrm{~g} \mathrm{~kg}^{-1}$; total carbon, $38.1 \mathrm{~g} \mathrm{~kg}^{-1}$; cation exchange capacity, $43.3 \mathrm{cmol}_{\mathrm{C}} \mathrm{kg}^{-1}$; and available phosphorus (Truog-P), $280 \mathrm{mg} \mathrm{P}_{2} \mathrm{O}_{5} \mathrm{~kg}^{-1}$. The mean annual temperature and precipitation for this region are $11.0^{\circ} \mathrm{C}$ and $1367 \mathrm{~mm}$, respectively [8].

Straw of staple rice cultivated in the experimental field in the year prior to this study was chopped and scattered in the field at the time of harvesting by a combine harvester in autumn; thereafter, it was left on the field throughout the fallow season. On 27 April, $2 \mathrm{~kg}-\mathrm{FW} \mathrm{m}{ }^{-2}$ of LMC made of a three-species livestock manure mixture (cattle, swine, and poultry: 7:3:2; carbon content, $183 \mathrm{~g} \mathrm{~kg}^{-1}$ (fresh matter); C/N ratio, 19.3; carbon application rate, $366 \mathrm{~g} \mathrm{~m}^{-2}$ ) produced at the Livestock Experiment Station, Akita Prefectural Agriculture, Forestry and Fisheries Research Center was applied to the $\mathrm{F}+\mathrm{M}$ plots. On 4 May, all of the plots were plowed to a depth of $10 \mathrm{~cm}$, and the rice straw 
and LMC were incorporated into the soil. Basal fertilizer $\left(4\right.$ and $7 \mathrm{~g} \mathrm{~N} \mathrm{~m}^{-2}$ for the staple and forage rice, respectively) was applied in a nursery box using a sigmoidal type of controlled-release (100 days) coated urea fertilizer $[14,15]$ without any top-dressing of fertilizer. The nitrogen application rate for the forage rice was increased compared to the conventional application rate for staple rice owing to its high requirement for nitrogen $[3,11]$. Phosphorus and potash were not applied with chemical fertilizer to all the plots. The amounts of nitrogen $(\mathrm{N})$, phosphorus $(\mathrm{P})$, and potash $(\mathrm{K})$ applied by LMC in the + M plot were 19.0, 10.1, and $31.3 \mathrm{~g} \mathrm{~m}^{-2}$, respectively. On 25 May, rice seedlings (approximately three seedlings per hill) were transplanted to the field at a density of 21.4 hills $\mathrm{m}^{-2}$. The control of weeds and pests was conducted by following local conventions. Mid-season drainage was not conducted, and irrigation was not conducted after the final drainage on $15 \mathrm{July}$. At the time of harvesting by a combine harvester in early October, rice straw was scattered on the field.

\subsection{GHG Flux Measurement}

The GHG $\left(\mathrm{CH}_{4}, \mathrm{~N}_{2} \mathrm{O}\right.$, and $\left.\mathrm{CO}_{2}\right)$ flux was measured using a closed-chamber method for one year (31 May 2011 to 17 May 2012). The measurement was conducted once a week during the rice growing season (31 May to 20 September 2011), one to two times per month during the following fallow season (October 2011 to May 2012).

\subsection{1. $\mathrm{CH}_{4}$ and $\mathrm{N}_{2} \mathrm{O}$ Fluxes}

For the measurement of $\mathrm{CH}_{4}$ and $\mathrm{N}_{2} \mathrm{O}$ fluxes during the rice growing season, a transparent acryl chamber $(30 \times 60 \times 50$ or $100 \mathrm{~cm}$, length $\times$ width $\times$ height $)$ with a detachable lid was used $[8,16]$. During the flux measurements, each chamber covered four hills of rice. To accommodate the heights of the rice plants, the chamber height was adjusted to 50 or $100 \mathrm{~cm}$ by stacking the chambers. At 1 , 11 , and $21 \mathrm{~min}$ after sealing the chamber, a 20-mL gas sample was taken from inside the chamber in a $10-\mathrm{mL}$ evacuated glass vial with a butyl rubber septum using a syringe. All operations were conducted from boardwalks placed in the field to avoid any disturbances.

During the fallow season, $\mathrm{CH}_{4}$ and $\mathrm{N}_{2} \mathrm{O}$ fluxes from soil were measured using cylindrical stainless-steel chambers $(18.5-21.0 \mathrm{~cm}$ in diameter and $25 \mathrm{~cm}$ in height) with detachable circular opaque lids $[17,18]$. A stainless-steel chamber base equipped with a groove for sealing by water was placed into the soil of each plot throughout the fallow period.

The soil temperature was measured at a depth of $5 \mathrm{~cm}$ simultaneously with each gas flux measurement throughout the measurement period. During the rice growing season, the soil redox potential (Eh) was measured at a depth of $5 \mathrm{~cm}$ simultaneously with each measurement of gas flux. The Eh was measured using platinum-tipped electrodes installed in duplicate with each sub-plot and a portable Eh meter (PRN-41, Fujiwara Scientific Company Co. Ltd., Tokyo, Japan).

\subsection{2. $\mathrm{CO}_{2}$ Flux (Organic Matter Decomposition)}

A bare soil plot $(50 \times 50 \mathrm{~cm})$ was established in the plots with and without LMC application to measure the $\mathrm{CO}_{2}$ emission derived from the organic matter decomposition. Polypropylene plates were inserted into the soil at a depth of $15 \mathrm{~cm}$ to prevent the penetration of roots into the plot [19,20]. The bare soil plots were set in duplicate with each sub-plot. As with the $\mathrm{CH}_{4}$ and $\mathrm{N}_{2} \mathrm{O}$ flux measurements during the fallow season (Section 2.2.1), the $\mathrm{CO}_{2}$ flux from soil surface was measured using a cylindrical stainless-steel chamber [17]. During the flooding period (from transplanting to final drainage), the chamber was carefully placed on the soil surface prior to each measurement. During the non-flooding period, the stainless-steel chamber base was placed into the soil. Before and $10 \mathrm{~min}$ after closing the chamber with a lid, a 250-mL gas sample was collected in a 500-mL sampling bag (Tedlar ${ }^{\circledR}$ bag). 


\subsubsection{Analysis and Calculation}

The $\mathrm{CH}_{4}$ or $\mathrm{N}_{2} \mathrm{O}$ concentrations were determined using a gas chromatograph (GC-14B, Shimadzu, Kyoto, Japan) equipped with a flame ionization detector (FID) and a 2-m Porapak Q 80/100-mesh column or an electron capture detector (ECD) and a 1-m of Porapak N 80/100-mesh column, respectively. One-mL samples were injected into both the GC. The injection, column oven, and detection temperatures were 120,80 , and $120^{\circ} \mathrm{C}$ for FID-GC and 250,60 , and $340{ }^{\circ} \mathrm{C}$ for ECD-GC, respectively. Pure helium gas or argon with $5 \% \mathrm{CH}_{4}$ gas were used as the carrier at a flow rate of $60 \mathrm{~mL} \mathrm{~min}^{-1}$ for FID-GC and ECD-GC, respectively. Standard $\mathrm{CH}_{4}$ gases $\left(1.99,10.5\right.$, and $102 \mu \mathrm{L} \mathrm{L}^{-1}$ with dinitrogen base) or $\mathrm{N}_{2} \mathrm{O}$ gases $\left(0.305,0.610\right.$, and $0.915 \mu \mathrm{L} \mathrm{L}^{-1}$ with dinitrogen base) were used for calibration. The $\mathrm{CO}_{2}$ concentrations were determined on the day of sampling using an infrared $\mathrm{CO}_{2}$ analyzer (ZFP9, Fuji Electrics, Tokyo, Japan) calibrated with standard $\mathrm{CO}_{2}$ gases $\left(0\right.$ and $1930 \mu \mathrm{L} \mathrm{L}^{-1}$ with dinitrogen base). The flux of GHGs was calculated using a linear regression of the changes in the gas concentrations inside the chamber and the measured time. Annual emissions of GHGs were calculated by integrating the daily flux by linear interpolation.

\subsection{Aboveground Dry Matter Weight of Rice and Net Primary Production (NPP)}

At the harvest stage (28 September), 16 rice hills were collected in duplicate from each sub-plot by cutting them at the ground. After drying and threshing, the dry matter weights of unhulled grain and rice straw were measured. Assuming that machine harvesting of forage rice for WCS use had occurred, the rice straw was divided into that above or below $15 \mathrm{~cm}$ from the ground [11]. The plant samples were ground using a cutting mill (SM 100, Retsch GmbH, Haan, Germany) and an ultra-centrifugal mill (ZM 100, Retsch GmbH). The total carbon content of the ground samples was measured using an N/C analyzer (SUMIGRAPH NC-22F; Sumika Chemical Analysis Service, Osaka, Japan) and the amount of carbon accumulation by parts was calculated. The amount of carbon accumulation in the whole aboveground plant was taken as the net primary production (NPP).

\subsection{Net Biome Production (Carbon Budget)}

The net biome production (NBP) was estimated as the difference between the input and output carbon flows (Equation (1)). The positive and negative values indicated the net carbon accumulation and loss in the field, respectively.

$$
\mathrm{NBP}=\mathrm{NPP}-\mathrm{OMD}-\mathrm{CH}_{4} \text { emission }+\mathrm{LMC}-\text { Harvest }
$$

where NPP is the net primary production, OMD is the organic matter decomposition, and LMC is the livestock manure compost (all units are $\mathrm{g} \mathrm{C} \mathrm{m}^{-2}$ year $^{-1}$ ). The organic matter decomposition in the $\mathrm{S}-\mathrm{M}$ and $\mathrm{F}-\mathrm{M}$ or $\mathrm{F}+\mathrm{M}$ plots was estimated by assigning the $\mathrm{CO}_{2}$ emission from the bare plot of the $-\mathrm{M}$ or $+\mathrm{M}$ plots, respectively. For harvest in the staple rice (the $\mathrm{S}-\mathrm{M}$ plot), the amount of carbon accumulation of the unhulled grain was used, assuming that harvesting had been done with a combine harvester (rice straw was scattered in the field). For the harvesting of the forage rice (the $\mathrm{F}-\mathrm{M}$ and $\mathrm{F}+\mathrm{M}$ plots), the amount of carbon accumulation of the unhulled grain and rice straw above $15 \mathrm{~cm}$ from the ground was used, assuming the utilization of WCS.

\subsection{Net GHG Balance}

The net GHG balance in the field was calculated by integrating the $\mathrm{CH}_{4}, \mathrm{~N}_{2} \mathrm{O}$, and $\mathrm{CO}_{2}$ emissions described above as $\mathrm{CO}_{2}$ equivalents (Equation (2)). All carbon loss estimated as NBP was assumed to contribute to $\mathrm{CO}_{2}$ emissions. The global warming potentials for $\mathrm{CH}_{4}$ and $\mathrm{N}_{2} \mathrm{O}$ were 25 and 298, respectively [21].

$$
\begin{aligned}
& \text { Net GHG balance }\left(\mathrm{kg} \mathrm{CO}_{2} \text {-eq m} \mathrm{eq}^{-2} \text { year }^{-1}\right)=\mathrm{CH}_{4}\left(\mathrm{~kg} \mathrm{CH}_{4} \mathrm{~m}^{-2} \text { year }^{-1}\right) \times \\
& 25+\mathrm{N}_{2} \mathrm{O}\left(\mathrm{kg} \mathrm{N}_{2} \mathrm{O} \mathrm{m}^{-2} \text { year }^{-1}\right) \times 298-\mathrm{NBP}\left(\mathrm{kg} \mathrm{C} \mathrm{m}^{-2} \text { year }^{-1}\right) \times 44 / 12 .
\end{aligned}
$$




\subsection{Statistical Analysis}

Differences among the treatments in dry matter weight of rice, GHG emissions, NBP, and net GHG balance were compared using a one-way analysis of variance (ANOVA) followed by a Tukey's test. In this study, differences with $p<0.10$ were considered significant. Excel Statistics 2012 for Windows (SSRI, Tokyo, Japan) was used for all statistical analyses.

\section{Results}

\subsection{GHG Fluxes}

The seasonal changes in soil temperature, soil redox potential (Eh, during rice growing season), $\mathrm{CH}_{4}, \mathrm{~N}_{2} \mathrm{O}$, and $\mathrm{CO}_{2}$ (from bare soil plot) fluxes are shown in Figure 1. There were no significant differences in soil temperature among the plots. During the rice growing season, the soil temperature ranged from 14 to $29^{\circ} \mathrm{C}$, and during the snow period in the winter, it remained at around $0^{\circ} \mathrm{C}$. The soil Eh in all plots decreased immediately after transplanting and then remained stable at approximately $-200 \mathrm{mV}$ until the final drainage occurred in the middle of July. The soil Eh increased after the final drainage and remained stable at approximately $+600 \mathrm{mV}$ until harvesting. Significant $\mathrm{CH}_{4}$ emissions were observed after 7 June, 13 days after transplanting, in all plots. The maximum $\mathrm{CH}_{4}$ emission was found on 20 June for the $\mathrm{F}-\mathrm{M}$ plot $\left(44.1 \mathrm{mg} \mathrm{C} \mathrm{m}^{-2} \mathrm{~h}^{-1}\right)$ and on $19 \mathrm{July}$, just after the final drainage for the other two plots (68.1 and $71.5 \mathrm{mg} \mathrm{C} \mathrm{m}^{-2} \mathrm{~h}^{-1}$ for the $\mathrm{S}-\mathrm{M}$ and $\mathrm{F}+\mathrm{M}$ plots, respectively). Throughout the flooding period, there were no significant differences in the $\mathrm{CH}_{4}$ flux among the plots. No significant $\mathrm{CH}_{4}$ fluxes were observed at 11 days after the final drainage (26 July) and later. During the flooding period, significant $\mathrm{N}_{2} \mathrm{O}$ emissions were hardly observed. The $\mathrm{N}_{2} \mathrm{O}$ flux tended to slightly increase after the final drainage. Throughout the measurement period, there were no significant differences in $\mathrm{N}_{2} \mathrm{O}$ flux among the plots. During the flooding period, the $\mathrm{CO}_{2}$ flux in all plots remained below $100 \mathrm{mg} \mathrm{C} \mathrm{m}^{-2} \mathrm{~h}^{-1}$. The $\mathrm{CO}_{2}$ flux gradually increased after the final drainage, and reached its maximum value on 4 August (284 and $244 \mathrm{mg} \mathrm{C} \mathrm{m}^{-2} \mathrm{~h}^{-1}$ for the $-\mathrm{M}$ and $+\mathrm{M}$ plots, respectively) before decreasing. During the fallow season, the $\mathrm{CO}_{2}$ flux generally changed with the change in the soil temperature. There were no significant differences in the $\mathrm{CO}_{2}$ flux between the plots throughout the measurement period.

The annual $\mathrm{CH}_{4}, \mathrm{~N}_{2} \mathrm{O}$, and $\mathrm{CO}_{2}$ emissions are shown in Table 1. The promotion of emission by LMC application was not found in all GHGs. Though the annual $\mathrm{CH}_{4}$ emissions from the $\mathrm{F}-$ $\mathrm{M}$ plot tended to be lower than those from the other plots, there were no significant differences in $\mathrm{CH}_{4}$ emissions among the plots. Though the annual $\mathrm{N}_{2} \mathrm{O}$ emissions from the $\mathrm{F}-\mathrm{M}$ plot tended to be higher than those from the other plots, there were no significant differences in $\mathrm{N}_{2} \mathrm{O}$ emissions among the plots. Though the annual $\mathrm{CO}_{2}$ emissions from the $+\mathrm{M}$ plot were lower than those from the $-\mathrm{M}$ plot, a significant difference was not found between them.

Table 1. Annual methane $\left(\mathrm{CH}_{4}\right)$ and nitrous oxide $\left(\mathrm{N}_{2} \mathrm{O}\right)$ emissions and carbon dioxide $\left(\mathrm{CO}_{2}\right)$ emissions derived from organic matter decomposition in a rice paddy field.

\begin{tabular}{cccccc}
\hline & $\mathbf{S}-\mathbf{M}$ & $\mathbf{F}-\mathbf{M}$ & $\mathbf{F}+\mathbf{M}$ & $-\mathbf{M}$ & $+\mathbf{M}$ \\
\hline $\mathrm{CH}_{4}\left(\mathrm{~g} \mathrm{C} \mathrm{m}^{-2}\right.$ year $\left.^{-1}\right)$ & $45.2 \pm 9.3^{\mathrm{a}}$ & $32.1 \pm 6.7^{\mathrm{a}}$ & $48.2 \pm 5.4^{\mathrm{a}}$ & - & - \\
$\mathrm{N}_{2} \mathrm{O}\left(\mathrm{mg} \mathrm{N} \mathrm{m}^{-2}\right.$ year $\left.^{-1}\right)$ & $51.9 \pm 48.0^{\mathrm{a}}$ & $64.1 \pm 38.2^{\mathrm{a}}$ & $55.7 \pm 2.3^{\mathrm{a}}$ & - & - \\
$\begin{array}{c}\mathrm{CO}_{2}\left(\text { Organic matter }_{\text {decomposition) }}\right. \\
\left(\mathrm{g} \mathrm{C} \mathrm{m}^{-2} \text { year }^{-1}\right)\end{array}$ & - & - & & $476 \pm 47^{\mathrm{a}}$ & $406 \pm 20^{\mathrm{a}}$ \\
\hline
\end{tabular}

Values represent the average \pm standard error $(n=2)$. Positive values indicate net emissions to the atmosphere. Numbers within a column followed by different letters differ significantly among the plots (one-way ANOVA followed by Tukey test, $p<0.10$ ). F, forage rice; $-\mathrm{M}$, without livestock manure compost application; $+\mathrm{M}$, with livestock manure compost application; $\mathrm{S}$, staple rice. 


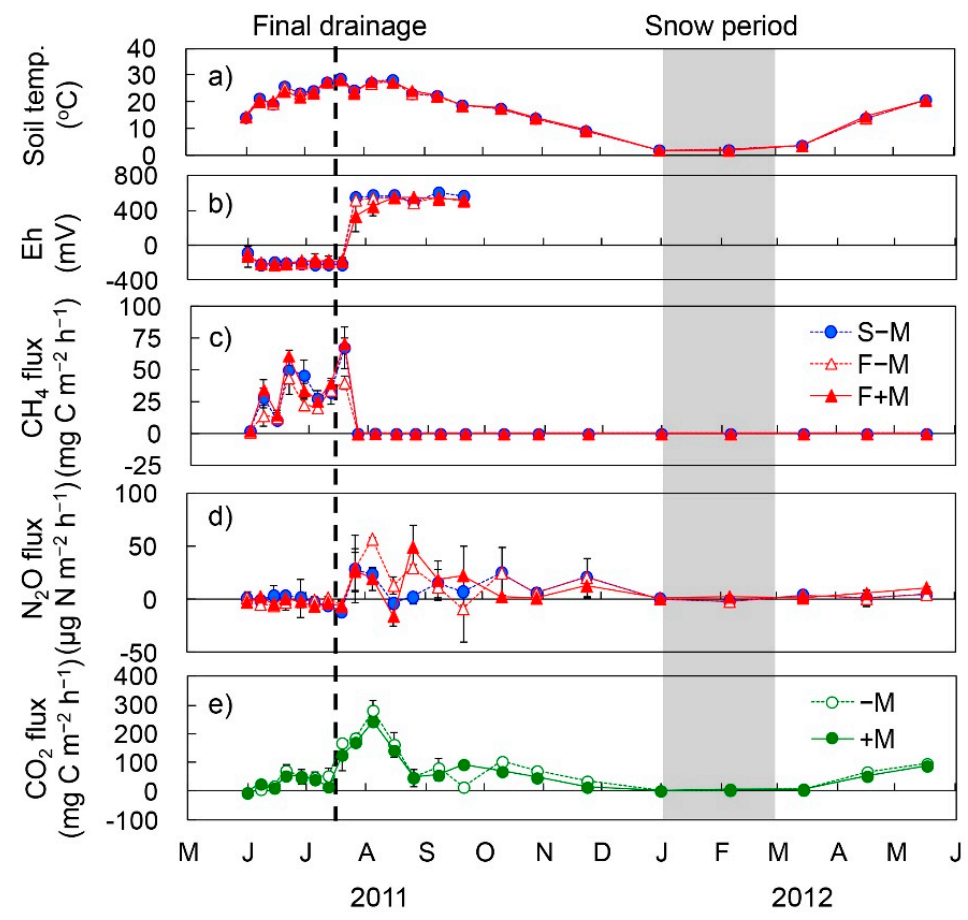

Figure 1. Seasonal changes in (a) soil temperature and (b) soil Eh as well as (c) methane $\left(\mathrm{CH}_{4}\right)$, (d) nitrous oxide $\left(\mathrm{N}_{2} \mathrm{O}\right)$, and (e) carbon dioxide $\left(\mathrm{CO}_{2}\right)$ fluxes. Positive flux values indicate emission to the atmosphere and negative values indicate uptake from the atmosphere. $\mathrm{F}$, forage rice; $-\mathrm{M}$, without livestock manure compost application; $+\mathrm{M}$, with livestock manure compost application; S, staple rice.

\subsection{Aboveground Dry Matter Weight of Rice at the Harvest Stage}

The aboveground dry matter weight of rice at the harvest stage is shown in Figure 2. The unhulled grain weights in both forage rice plots (767 and $764 \mathrm{~g} \mathrm{~m}^{-2}$ for $\mathrm{F}-\mathrm{M}$ and $\mathrm{F}+\mathrm{M}$ plots, respectively) were higher than those in the staple rice plot (the $\mathrm{S}-\mathrm{M}$ plot, $664 \mathrm{~g} \mathrm{~m}^{-2}$ ). There were no significant differences in the aboveground dry matter weight among the plots $\left(1268-1368 \mathrm{~g} \mathrm{~m}^{-2}\right.$ ). The proportion of harvested products (unhulled grain) in aboveground dry matter weight in the $\mathrm{S}-\mathrm{M}$ plot was $56 \%$. In forage rice plots, assuming harvest for WCS occurred, it was estimated that $89-90 \%$ of the aboveground dry matter would be removed from the field due to the harvesting of unhulled grain and rice straw above $15 \mathrm{~cm}$ from the ground.

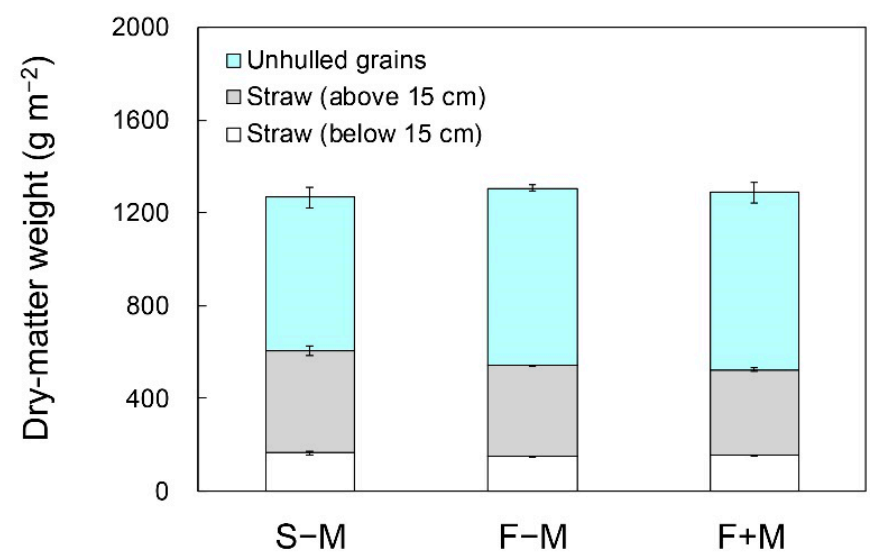

Figure 2. Aboveground dry-matter weight of rice at the harvesting stage. Significant differences were not found among the plots (one-way ANOVA followed by Tukey test, $p<0.10$ ). F, forage rice; $-\mathrm{M}$, without livestock manure compost application; $+\mathrm{M}$, with livestock manure compost application; $\mathrm{S}$, staple rice. 


\subsection{Net Biome Production (Carbon Budget)}

The carbon budget (NBP) in the field is shown in Table 2. In the S - M plot, the carbon output consisted of organic decomposition and harvest (unfulled grain), and the $\mathrm{CH}_{4}$ emissions exceeded the carbon input indicated by NPP, resulting in a negative NBP $\left(-299 \mathrm{~g} \mathrm{C} \mathrm{m}^{-2}\right.$ year $\left.^{-1}\right)$. The negative value of NBP (carbon loss) in the $\mathrm{F}-\mathrm{M}$ plot $\left(-457 \mathrm{~g} \mathrm{C} \mathrm{m}^{-2}\right.$ year $\left.^{-1}\right)$ was significantly higher than that in the $\mathrm{S}-\mathrm{M}$ plot due to the additional carbon output for the harvest of rice straw above $15 \mathrm{~cm}$ from the ground. On the other hand, the negative NBP (carbon loss) in the forage rice cultivation was improved by carbon input with LMC application, and the negative value of NBP in the F+M $\left(-40 \mathrm{~g} \mathrm{C} \mathrm{m}^{-2}\right.$ year $\left.{ }^{-1}\right)$ was significantly lower than that in the other plots. In addition, assuming that feed rice was cultivated to harvest and only unhulled grain was removed, the NBP in the F + M plot had a positive value $\left(+89 \mathrm{~g} \mathrm{C} \mathrm{m}^{-2}\right.$ year $\left.^{-1}\right)$ indicating carbon accumulation in the field.

Table 2. Effects of forage rice cultivation on the carbon flow and net biome production (NBP) in a rice paddy field.

\begin{tabular}{|c|c|c|c|c|}
\hline & & \multicolumn{3}{|c|}{ Carbon Flow $\left(\mathrm{g} \mathrm{C} \mathrm{m}^{-2}\right.$ year $\left.^{-1}\right)$} \\
\hline & & $\mathbf{S}-\mathbf{M}$ & $\mathbf{F}-\mathbf{M}$ & $\mathbf{F}+\mathbf{M}$ \\
\hline \multirow[t]{2}{*}{ Input } & $\begin{array}{l}\text { Net primary production } \\
\text { (Photosynthesis) }\end{array}$ & $500 \pm 19$ & $508 \pm 2$ & $501 \pm 4$ \\
\hline & Livestock manure compost & - & - & 363 \\
\hline \multirow{4}{*}{ Output } & ${ }^{\dagger}$ Organic matter decomposition & $476 \pm 47$ & $476 \pm 47$ & $406 \pm 20$ \\
\hline & $\mathrm{CH}_{4}$ emission & $45 \pm 9$ & $32 \pm 7$ & $48 \pm 5$ \\
\hline & Harvest (Unhulled grains) & $278 \pm 10$ & $321 \pm 3$ & $321 \pm 8$ \\
\hline & Harvest (Straw) & - & $137 \pm 6$ & $130 \pm 3$ \\
\hline \multicolumn{2}{|c|}{$\begin{array}{c}\ddagger \text { NBP } \\
\text { (Without straw harvesting in forage rice) }\end{array}$} & $\begin{array}{c}-299 \pm 34^{b} \\
-\end{array}$ & $\begin{array}{l}-457 \pm 40^{a} \\
(-320 \pm 40)\end{array}$ & $\begin{aligned}-40 & \pm 12^{\mathrm{c}} \\
(89 & \pm 8)\end{aligned}$ \\
\hline
\end{tabular}

Values represent the average \pm standard error (except for livestock manure compost). Positive and negative values indicate the carbon input and output, respectively. The carbon budget (NBP) was calculated by subtracting the carbon output from the input. ${ }^{\dagger}$ Organic matter decomposition in $\mathrm{S}-\mathrm{M}$ and $\mathrm{F}-\mathrm{M}$ or $\mathrm{F}+\mathrm{M}$ was estimated by assigning the value of the $-\mathrm{M}$ or $+\mathrm{M}$ plot (Table 1$)$. $\ddagger$ Numbers within a column followed by different letters differ significantly among the plots (one-way ANOVA followed by Tukey test, $p<0.10$ ). F, forage rice; $-\mathrm{M}$, without livestock manure compost application; $+\mathrm{M}$, with livestock manure compost application; $\mathrm{S}$, staple rice.

\subsection{Net GHG Balance}

The net GHG balance is shown in Table 3. The major component of the net GHG balance was the $\mathrm{CO}_{2}$ and $\mathrm{CH}_{4}$ emissions (8-60\% and $39-90 \%$ of the total, respectively). The net GHG balance in the $\mathrm{F}+\mathrm{M}$ plot $\left(1.78 \mathrm{~kg} \mathrm{CO}_{2}\right.$-eq m${ }^{-2}$ year $^{-1}$ ) was significantly lower than that in the other plots (2.63-2.77 $\mathrm{kg} \mathrm{CO}_{2}$-eq $\mathrm{m}^{-2}$ year $^{-1}$ ) owing to its low $\mathrm{CO}_{2}$ emission. In addition, the value could be decreased by $0.5 \mathrm{~kg} \mathrm{CO}_{2}$-eq m${ }^{-2}$ year $^{-1}$ assuming the cultivation of rice for feed.

Table 3. Effects of forage rice cultivation on net greenhouse gas (GHG) balance in a rice paddy field.

\begin{tabular}{cccc}
\hline & \multicolumn{3}{c}{${ }^{\dagger}$ Net GHG Balance $\mathbf{k g ~ C O}_{\mathbf{2}}$-eq $\mathbf{~}^{-\mathbf{2}}$ year $^{-\mathbf{1}}$ ) } \\
\cline { 2 - 4 } & $\mathbf{S}-\mathbf{M}$ & $\mathbf{F}-\mathbf{M}$ & $\mathbf{F}+\mathbf{M}$ \\
\hline $\mathrm{CO}_{2}(-\mathrm{NBP})$ & $1.10 \pm 0.12$ & $1.67 \pm 0.15$ & $0.15 \pm 0.04$ \\
$\mathrm{CH}_{4}$ & $1.51 \pm 0.31$ & $1.07 \pm 0.22$ & $1.61 \pm 0.01$ \\
$\mathrm{~N}_{2} \mathrm{O}$ & $0.02 \pm 0.02$ & $0.03 \pm 0.02$ & $0.03 \pm 0.00$ \\
\hline$\ddagger$ Total & $2.63 \pm 0.16^{\mathrm{b}}$ & $2.77 \pm 0.06^{\mathrm{b}}$ & $1.78 \pm 0.13^{\mathrm{a}}$ \\
(Without straw harvesting in forage rice) & - & $(2.27 \pm 0.06)$ & $(1.30 \pm 0.15)$ \\
\hline
\end{tabular}

Values represent the average \pm standard error $(n=2)$. Positive values indicate net emissions to the atmosphere. ${ }^{\dagger}$ Calculated using the GWP of $\mathrm{CO}_{2}: \mathrm{CH}_{4}: \mathrm{N}_{2} \mathrm{O}=1: 25: 298$ [21]. ${ }^{\ddagger}$ Numbers within a column followed by different letters differ significantly among the plots (one-way ANOVA followed by Tukey test, $p<0.10$ ). F, forage rice; $-\mathrm{M}$, without livestock manure compost application; $+\mathrm{M}$, with livestock manure compost application; $\mathrm{S}$, staple rice. 


\section{Discussion}

No significant differences in $\mathrm{CH}_{4}$ emissions were shown between the varieties (Figure 1, Table 1). However, many differences in $\mathrm{CH}_{4}$ emissions have previously been reported between rice varieties [22-24]. Recently, forage rice varieties with large biomass were reported to have larger $\mathrm{CH}_{4}$ emissions than an edible (staple) rice variety, and the difference was considered to be caused by the difference in $\mathrm{CH}_{4}$ production from newly produced root exudates and plant debris through plant photosynthesis [25]. Root exudates and plant (mainly root) debris are regarded as the major substrates of $\mathrm{CH}_{4}$ emissions in the latter part of the rice growing season [26]. In this study, since the soil was in an oxidative state after the final drainage (15 July), the production of $\mathrm{CH}_{4}$ production during the latter part of the rice growing season was considered to be suppressed strongly. So, there is a possibility that there were no significant differences in $\mathrm{CH}_{4}$ emissions between the varieties.

The application of LMC did not increase the $\mathrm{CH}_{4}$ emissions or the organic matter decomposition $\left(\mathrm{CO}_{2}\right.$ emissions from the bare soil plot) (Figure 1, Table 1). The tendency for $\mathrm{CH}_{4}$ emissions to increase following the application of organic matter varies depending on the type of organic matter. $\mathrm{The}^{\mathrm{CH}}$ production potential of compost derived from cattle manure with a low content of easily decomposable organic matter was reported to be lower than that of pig and poultry manure [27,28]. Since the LMC used in this experiment was derived mainly from cattle manure, there was a possibility that $\mathrm{CH}_{4}$ and $\mathrm{CO}_{2}$ production following organic matter decomposition did not increase due to its low content of easily decomposable organic matter. The influence of applying compost derived from other livestock species on $\mathrm{CH}_{4}$ and $\mathrm{CO}_{2}$ emissions should be studied in the future. In addition, since this study evaluated the GHG balance in the first year of conversion from staple rice to forage rice, both rice straw and compost were applied to the field. It has been reported that the application of rice straw to paddy fields greatly increases $\mathrm{CH}_{4}$ emissions [8-10]. Besides, the $\mathrm{CH}_{4}$ production potential of cattle manure compost is considered to be lower than that of rice straw $[27,28]$. Although it is rare to evaluate the effect of the combined application of LMC and rice straw on $\mathrm{CH}_{4}$ emissions from paddy fields, in this study, there was a possibility that changes in $\mathrm{CH}_{4}$ emission due to LMC application could not be clarified due to masking by large $\mathrm{CH}_{4}$ emissions derived from rice straw.

The application of LMC also did not increase the $\mathrm{N}_{2} \mathrm{O}$ emissions (Figure 1, Table 1). The cumulative $\mathrm{N}_{2} \mathrm{O}$ emissions (51.9-64.1 $\mathrm{mg} \mathrm{N} \mathrm{m}^{-2}$ ) were higher than the reported value from a continuous paddy field in Yamagata Prefecture adjacent to the studied site ( -31.8 to $25.5 \mathrm{mg} \mathrm{N} \mathrm{m}^{-2}$ ) [29], and comparable to the average value $\left(66.7 \mathrm{mg} \mathrm{N} \mathrm{m}^{-2}\right)$ of $\mathrm{N}_{2} \mathrm{O}$ emissions from the Japanese paddy fields [30]. It has been reported that the nitrogen mineralization rates of cattle manure sawdust compost $(\mathrm{C} / \mathrm{N}$ ratio: 20-23) applied to paddy fields during the early rice growing period (around 50 days) in the current year is estimated to be as low as around 10\% [31,32]. By applying the rate, the amount of inorganic nitrogen released from the LMC applied was estimated to be only $1.9 \mathrm{~g} \mathrm{~m}^{-2}$. The minor supply of inorganic nitrogen might not influence the $\mathrm{N}_{2} \mathrm{O}$ emissions significantly.

The aboveground dry matter weight and carbon accumulation (NPP) of rice were similar among the plots (Figure 2, Table 2). It has been reported that "Bekoaoba", a variety of forage rice, can show a large dry matter production (1.3 times of this study) under high application of nitrogen fertilizer $\left(18 \mathrm{~g} \mathrm{~m}^{-2}\right)$ [33]. As the biomass production of rice increases, the amount of rice straw below $15 \mathrm{~cm}$ from the ground which remains in the field at harvesting could increase and carbon loss could be mitigated. On the other hand, as described above, there is a possibility that an increase in plant biomass could result in an increase in $\mathrm{CH}_{4}$ emissions during the rice growing season. Therefore, it is necessary to evaluate the trade-off relationship between them.

The carbon balance (NBP) in the staple rice cultivation (the $\mathrm{S}-\mathrm{M}$ plot, harvest of unhulled grain and return of rice straw to the field) was $-299 \mathrm{~g} \mathrm{C} \mathrm{m}^{-2}$ year $^{-1}$, indicating a net loss of carbon (Table 2). The carbon loss was larger than the previously reported values in the central part of Japan ( -20 to $-104 \mathrm{~g} \mathrm{C} \mathrm{m}^{-2}$ year $^{-1}$ (loss): [34] and 79 to $137 \mathrm{~g} \mathrm{C} \mathrm{m}^{-2}$ year $^{-1}$ (accumulation): [35]), and was close to the values of uplands in northern Japan $\left(-147\right.$ to $-410 \mathrm{~g} \mathrm{C} \mathrm{m}^{-2}$ year $^{-1}$, [36,37]). The large loss of carbon could be caused by enhanced organic matter decomposition due to the early final drainage 
(the middle of July) in this study. The $\mathrm{CO}_{2}$ emission from the water/soil surface was hardly observed during the flooding period, and it increased greatly after the final drainage (Figure 1). This agreed well with the previous observations $[38,39]$. The studied field was not flooded from late July to August with high air temperature, and the $\mathrm{CO}_{2}$ emission was high, resulting in the large carbon loss. Though the studied site located in a snowy cool-temperate region and the $\mathrm{CO}_{2}$ emission in winter was extremely low, the annual organic matter decomposition $\left(406-476 \mathrm{~g} \mathrm{C} \mathrm{m}^{-2}\right.$ year $^{-1}$ ) was comparable with the $\mathrm{CO}_{2}$ emission including root respiration from paddy fields located in central Japan, warmer than this region (357-491 $\mathrm{g} \mathrm{C} \mathrm{m}^{-2}$ year $^{-1}$, [39]).

It was shown that LMC application effectively mitigates carbon loss and suppresses GHG emissions in the paddy field in the first year of conversion from staple rice to forage rice for WCS (Tables 2 and 3). It seems likely that the suppression of GHG emissions by cattle-based livestock cooperation between cattle-based livestock production and rice paddy-based cultivation is possible. In particular, the application of LMC increased carbon input significantly, whereas it did not increase $\mathrm{CH}_{4}$ emissions and organic matter decomposition. If forage rice cultivation for WCS is continued, its impact on GHG balance will change. Unlike the first year of conversion from staple rice to forage rice for WCS, when forage rice cultivation for WCS is repeated, most of the rice straw produced in the previous year's rice cultivation is removed from the field. So, the $\mathrm{CH}_{4}$ emissions can be reduced compared to staple rice cultivations in which rice straws are returned to the field and the suppressing effect on GHG emission by forage rice cultivation is found more clearly than in the first year shown in this article. However, even for LMC with a low content of easily decomposable organic matter, continuous application could increase soil carbon storage, resulting in an increase in $\mathrm{CH}_{4}$ emissions. In addition, there is a possibility that increased soil nitrogen fertility due to continuous application of LMC (e.g., [6]) promotes growth of rice, resulting in an increase in carbon fixation by rice plants and $\mathrm{CH}_{4}$ emissions. The increase in soil carbon and nitrogen storage by continuous application of LMC could also increase $\mathrm{N}_{2} \mathrm{O}$ emission owing to increase in supply of substrate (ammonium and nitrate) and electron donor for the process of nitrification and denitrification. Moreover, continuous application of LMC also has a negative influence on the surrounding water environment due to, for example, an increase in nitrogen and phosphorus leaching [40]. Due to these points, it is necessary to clarify the influence of continuous cultivation of forage rice including LMC application in the future.

Unlike WCS, rice for feed can be cultivated using agricultural machineries that are currently owned by rice farmers, so it is easy to lower production costs. There is also the possibility that the cultivation of rice for feed will increase in the future. During the cultivation of rice for feed harvesting using only unhulled grain, straw is returned to the field at the timing of harvesting. In particular, since high-yield rice varieties tend to be selected for rice for feed [2,3], the amount of rice straw returned to the field also increases. The supply of large amounts of rice straw could mitigate carbon loss in the field, but it could cause an increase in $\mathrm{CH}_{4}$ emissions [10,41] and inhibition of the early growth of rice [42] by extreme soil reduction in the following year. In order to avoid those risks, the enhancement of rice straw decomposition during the fallow season $[43,44]$ is considered to be important.

\section{Conclusions}

In the first year of forage rice cultivation converted from staple rice cultivation, LMC application to a paddy field improved the carbon balance by large input of carbon, whereas it did not enhance $\mathrm{CH}_{4}$ emission significantly. It suggested a possibility to suppress $\mathrm{GHG}$ emissions from paddy fields by the conversion. In the future, it is necessary to evaluate the effect of continuous cultivation of forage rice on the carbon and GHG balance.

Author Contributions: F.T. and Y.K. conceived and designed the experiments; F.T. and M.K. performed the experiments, analyzed the data, and wrote the paper; K.Y. contributed cultivation and field measurements; T.S. and Y.K. gave many constructive comments on this manuscript.

Acknowledgments: The authors would like to thank the staff members of the Center of Field Education and the Research, Faculty of Bioresource Sciences, Akita Prefectural University for their support with the management of 
the experimental field. The authors would also like to thank Hiroko Sato (Livestock Experiment Station, Akita Prefectural Agriculture, Forestry and Fisheries Research Center) for providing the forage rice (Bekoaoba) seed and livestock manure compost.

Conflicts of Interest: The authors declare no conflict of interest.

\section{References}

1. Ministry of Agriculture, Forestry and Fisheries (MAFF). Situation over Feed. Available online: http:/ / www. maff.go.jp/j/chikusan/sinko/lin/1_siryo/attach/pdf/index-293.pdf (accessed on 24 November 2018).

2. Kato, H. Development of rice varieties for whole crop silage (WCS) in Japan. JARQ 2008, 42, $231-236$. [CrossRef]

3. Fukushima, A.; Ohta, H.; Yokogami, N.; Tsuda, N. Yielding ability of rice varieties and lines for feed in the Tohoku region of Japan. Jpn. J. Crop. Sci. 2018, 87, 30-36. (In Japanese with English summary) [CrossRef]

4. Ohdaira, Y.; Nishida, M.; Fukujyu, N.; Mochida, H.; Ishikawa, H.; Katsube, T.; Saitoh, S.; Kikuchi, K.; Ono, H.; Shiratsuchi, H.; et al. Effect of swine compost application and the nitrogen application method on grain yield and protein content in brown rice of the high-yielding rice cultivar 'Iwaidawara' in the Tohoku region. Bull. NARO Agric. Res. Tohoku Reg. 2018, 120, 47-66 (In Japanese with English summary)

5. Shirato, Y.; Yagasaki, Y.; Nishida, M. Using different versions of the Rothamsted carbon model to simulate soil carbon in long-term experimental plots subjected to paddy-upland rotation in Japan. Soil Sci. Plant Nutr. 2011, 57, 597-606. [CrossRef]

6. Nishida, M. Decline in fertility of paddy soils induced by paddy rice and upland soybean rotation, and measures against the decline. JARQ 2016, 50, 87-94. [CrossRef]

7. National Institute for Environmental Studies. National Greenhouse Gas Inventory Report of Japan; Greenhouse Gas Inventory Office of Japan, Center for Global Environmental Research, National Institute for Environmental Studies: Tsukuba, Japan, 2018; pp. 26-27.

8. Takakai, F.; Ichikawa, J.; Ogawa, M.; Ogaya, S.; Yasuda, K.; Kobayashi, Y.; Sato, T.; Kaneta, Y.; Nagahama, K. Suppression of $\mathrm{CH}_{4}$ emission by rice straw removal and application of bio-ethanol production residue in a paddy field in Akita, Japan. Agriculture 2017, 7, 21. [CrossRef]

9. Yagi, K.; Minami, K. Effect of organic matter application on methane emission from some Japanese paddy fields. Soil Sci. Plant Nutr. 1990, 36, 599-610. [CrossRef]

10. Watanabe, A.; Satoh, Y.; Kimura, M. Estimation of the increase in $\mathrm{CH}_{4}$ emission from paddy soils by rice straw application. Plant Soil 1995, 173, 225-231. [CrossRef]

11. Nakagomi, K.; Yamaguchi, M.; Kataoka, T.; Endo, T.; Takata, T.; Higashi, T.; Yokogami, N.; Kato, H.; Tamura, Y. Breeding of a new rice cultivar, "Bekoaoba", for whole-crop silage adapted to direct seeding cultivation. Bull. Natl. Agric. Res. Cent. Tohoku Reg. 2006, 106, 1-14, (In Japanese with English summary).

12. Nagata, K.; Yoshinaga, S.; Terashima, K.; Fukuda, A. Growth, yield and dry matter production of rice varieties for whole-crop silage bred for the Tohoku region of Japan. Bull. Natl. Agric. Res. Cent. Tohoku Reg. 2007, 107, 63-70. (In Japanese with English summary)

13. FAO (Food and Agriculture Organization of the United Nations). World Reference Base for Soil Resources; FAO: Rome, Italy, 2006.

14. Kaneta, Y. Single application of controlled availability fertilizer to nursery boxes in non-tillage rice culture. JARQ 1995, 29, 111-116.

15. Kumagai, K.; Konno, Y.; Kuroda, J.; Ueno, M. The single application of fertilizer in nursery box on rice culture. Bull. Yamagata Agric. Exp. Stn. 1999, 33, 29-43. (In Japanese with English summary)

16. Takakai, F.; Nakagawa, S.; Sato, K.; Kon, K.; Sato, T.; Kaneta, Y. Net greenhouse gas budget and soil carbon storage in a field with paddy-upland rotation with different history of manure application. Agriculture 2017, 7, 49. [CrossRef]

17. Toma, Y.; Hatano, R. Effect of crop residue C:N ratio on $\mathrm{N}_{2} \mathrm{O}$ emissions from Gray Lowland soil in Mikasa, Hokkaido, Japan. Soil Sci. Plant Nutr. 2007, 53, 198-205. [CrossRef]

18. Takakai, F.; Takeda, M.; Kon, K.; Inoue, K.; Nakagawa, S.; Sasaki, K.; Chida, A.; Sekiguchi, K.; Takahashi, T.; Sato, T.; et al. Effects of preceding compost application on the nitrogen budget in an upland soybean field converted from a rice paddy field on gray lowland soil in Akita, Japan. Soil Sci. Plant Nutr. 2010, 56, 760-772. [CrossRef] 
19. Shimizu, M.; Marutani, S.; Desyatkin, A.R.; Jin, T.; Hata, H.; Hatano, R. The effect of manure application on carbon dynamics and budgets in a managed grassland of Southern Hokkaido, Japan. Agric. Ecosyst. Environ. 2009, 130, 31-40. [CrossRef]

20. Toma, Y.; Takakai, F.; Darung, U.; Kuramochi, K.; Limin, S.H.; Dohong, S.; Hatano, R. Nitrous oxide emission derived from soil organic matter decomposition from tropical agricultural peat soil in central Kalimantan, Indonesia. Soil Sci. Plant Nutr. 2010, 57, 436-451. [CrossRef]

21. Intergovernmental Panel on Climate Change (IPCC). The Physical Science Basis. Contribution of Working Group I to the Fourth Assessment Report of the Intergovernmental Panel on Climate Change. In Climate Change 2007; Solomon, S., Qin, D., Manning, M., Eds.; Cambridge University Press: Cambridge, UK, 2007.

22. Aulakh, M.S.; Wassmann, R.; Rennenberg, H. Methane transport capacity of twenty-two rice cultivars from five major Asian rice-growing countries. Agric. Ecosyst. Environ. 2002, 91, 59-71. [CrossRef]

23. Lou, Y.; Inubushi, K.; Mizuno, T.; Hasegawa, T.; Lin, Y.; Sakai, H.; Cheng, W.; Kobayashi, K. CH $\mathrm{CH}_{4}$ emission with differences in atmospheric $\mathrm{CO}_{2}$ enrichment and rice cultivars in a Japanese paddy soil. Glob. Chang. Biol. 2008, 14, 2678-2687.

24. Zhang, Y.; Jiang, Y.; Li, Z.; Zhu, X.; Wang, X.; Chen, J.; Hang, X.; Deng, A.; Zhang, J.; Zhang, W. Aboveground morphological traits do not predict rice variety effects on $\mathrm{CH}_{4}$ emissions. Agric. Ecosyst. Environ. 2015, 208, 86-93. [CrossRef]

25. Cheng, W.; Kimani, S.M.; Kanno, T.; Tang, S.; Oo, A.Z.; Tawaraya, K.; Sudo, S.; Sasaki, Y.; Yoshida, N. Forage rice varieties Fukuhibiki and Tachisuzuka emit larger $\mathrm{CH}_{4}$ than edible rice Haenuki. Soil Sci. Plant Nutr. 2018, 64, 77-83. [CrossRef]

26. Watanabe, A.; Takeda, T.; Kimura, M. Evaluation of carbon origins of $\mathrm{CH}_{4}$ emitted from rice paddies. J. Geophys. Res. 1999, 104, 23623-23630. [CrossRef]

27. Kumagai, K.; Shiono, H.; Morioka, M.; Nagasawa, K.; Nakagawa, F. Effect of application of livestock dung compost instead of spring incorporation of rice straw on methane emission from paddy fields in Yamagata. Bull. Agric. Res. Yamagata Prefect 2010, 2, 1-18.

28. Nagumo, Y.; Oyanagi, W.; Tanahashi, T. Estimate of methane emission potential of organic matter from amount of acid detergent soluble organism. Jpn. J. Soil Sci. Plant Nutr. 2016, 87, 455-457. (In Japanese)

29. Shiono, H.; Saito, H.; Nakagawa, F.; Nishimura, S.; Kumagai, K. Effects of crop rotation and rice straw incorporation in spring on methane and nitrous oxide emissions from an upland paddy field in a cold region of Japan. Jpn. J. Soil Sci. Plant Nutr. 2014, 85, 420-430. (In Japanese with English summary)

30. Akiyama, H.; Yagi, K.; Yan, X.Y. Direct $\mathrm{N}_{2} \mathrm{O}$ emissions from rice paddy fields: Summary of available data. Glob. Biogeochem. Cycles 2005, 19, GB1005. [CrossRef]

31. Nishida, M.; Usui, M.; Tuschiya, K.; Moriizumi, M. Demonstration of discrepancy in N remaining rate of organic matter evaluated by $\mathrm{N}$ content and ${ }^{15} \mathrm{~N}$ content in the glass fiber-filter paper bag method. Soil Sci. Plant Nutr. 2003, 49, 297-300. [CrossRef]

32. Shindo, H.; Kaneta, Y.; Kato, M.; Sakamoto, K.; Sato, H.; Togashi, Y.; Fujiwara, H. Machine broadcasting and nitrogen mineralization characteristics of the compost pellet made from animal waste. Tohoku Agric. Res. 2002, 55, 41-42. (In Japanese)

33. Tsuchiya, K.; Nishida, M.; Yoshida, K.; Kawamoto, H. The effects of matured cattle manure and nitrogen fertilizer on the growth and yield of transplanted rice variety "Bekoaoba" for whole crop silage. Tohoku Agric. Res. 2012, 65, 11-12. (In Japanese)

34. Minamikawa, K.; Sakai, N. Soil carbon budget in a single-cropping paddy field with rice straw application and water management based on soil redox potential. Soil Sci. Plant Nutr. 2007, 53, 657-667. [CrossRef]

35. Nishimura, S.; Yonemura, S.; Sawamoto, T.; Shirato, Y.; Akiyama, H.; Sudo, S.; Yagi, K. Effect of land use change from paddy rice cultivation to upland crop cultivation on soil carbon budget of a cropland in Japan. Agric. Ecosyst. Environ. 2008, 125, 9-20. [CrossRef]

36. Hu, R.; Hatano, R.; Kusa, K.; Sawamoto, T. Soil respiration and net ecosystem production in an onion field in central Hokkaido, Japan. Soil Sci. Plant Nutr. 2004, 50, 27-33. [CrossRef]

37. $\mathrm{Mu}, \mathrm{Z}$; Kimura, S.D.; Hatano, R. Estimation of global warming potential from upland cropping systems in central Hokkaido, Japan. Soil Sci. Plant Nutr. 2006, 52, 371-377. [CrossRef]

38. Minamikawa, K.; Sakai, N. The practical use of water management based on soil redox potential for decreasing methane emission from a paddy field in Japan. Agric. Ecosyst. Environ. 2006, 116, 181-188. [CrossRef] 
39. Nishimura, S.; Yonemura, S.; Minamikawa, K.; Yagi, K. Seasonal and diurnal variations in net carbon dioxide flux throughout the year from soil in paddy field. J. Geophys. Res. Biogeosci. 2015, 120, 63-76. [CrossRef]

40. Kusa, K.; Abe, K.; Ishikawa, T. Effects of cattle manure application on the leaching of nitrogen, phosphorus, and potassium from forage rice paddies-Results from lysimeter experiments. Jpn. J. Grassl. Sci. 2015, 61, 74-82. (In Japanese with English summary)

41. Naser, H.M.; Nagata, O.; Tamura, S.; Hatano, R. Methane emissions from five paddy fields with different amounts of rice straw application in central Hokkaido, Japan. Soil Sci. Plant Nutr. 2007, 53, 95-101. [CrossRef]

42. Kobayashi, A.; Suzuki, Y.; Saiten, H.; Morooka, M.; Ishida, H. Effects of early release of ponding water on growth and yield of wetland rice under heavy application if rice straw in clayey gley paddy soil. Bull. Hokuriku Agric. Exp. Stn. 2000, 43, 25-45. (In Japanese)

43. Miura, Y. Rice straw management for mitigation of methane emission from paddy field. Spec. Bull. Fukushima Prefect. Agric. Exp. Stn. 2003, 7, 1-38. (In Japanese)

44. Goto, E.; Miyamori, Y.; Hasegawa, S.; Inatsu, O. Reduction effects of accelerating rice straw decomposition and water management on methane emission from paddy fields in a cold distinct. Jpn. J. Soil Sci. Plant Nutr. 2004, 75, 191-201. (In Japanese)

(C) 2018 by the authors. Licensee MDPI, Basel, Switzerland. This article is an open access article distributed under the terms and conditions of the Creative Commons Attribution (CC BY) license (http:/ / creativecommons.org/licenses/by/4.0/). 